\title{
DELITOS CONTRA LAS RELACIONES FAMILIARES. ESPECIAL REFERENCIA A LA ÍNTIMA CONEXIÓN ENTRE EL ART. 224.2 Y EL ART. 225 BIS CP
}

\author{
Cristina Callejón Hernández \\ Universidad de Jaén \\ E-mail: chernand@ujaen.es
}

\begin{abstract}
RESUMEN: El art. $224.2 \mathrm{CP}$ y el art. 225 bis CP sancionan conductas que presentan elementos comunes. Así, ambos comportamientos son realizados principalmente por los titulares de la patria potestad y el objeto material recae sobre los hijos menores de edad. La relación que existe entre ellos es de un concurso de normas que deberá resolverse en atención al principio de especialidad, dependiendo de la edad y madurez del hijo menor. Sin embargo, tampoco puede olvidarse que existirá un gran número de supuestos que serán atípicos atendiendo a la libre decisión de aquel.

Palabras clave: sustracción de menores, inducción a la infracción del régimen de custodia, responsabilidad parental, menores de edad, menores de edad con cierta madurez.
\end{abstract}

ABSTRACT: Art. 224.2 PC and Art. 225 bis PC punish conducts that have common elements. Thus, both behaviours are mainly carried out by the holders of parental authority and the material object falls on minor children. They are two different rules which can be applied so the most suitable one should be selected, depending on the age and maturity of the minor child. However, it should not be forgotten that there will be a large number of cases that are not offences, depending on the free decision of the minor child.

Keywords: child abduction, inducement to breach of custody, parental responsibility, minors, minors of a certain maturity.

SUMARIO: I. INTRODUCCIÓN. II. ANÁLISIS DE LA FIGURA CONTENIDA EN EL ART. 224.2 CP. III. ANÁLISIS DE LA FIGURA CONTENIDA EN EL ART. 225 BIS CP. IV. RELACIÓN ENTRE AMBOS PRECEPTOS.

\section{INTRODUCCIÓN}

La Ley Orgánica 9/2002, de 10 de diciembre, de modificación de la Ley Orgánica 10/1995, de 23 de noviembre, del Código Penal, y del Código Civil, sobre sustracción de menores 
trajo consigo la incorporación al Texto punitivo de dos nuevas figuras delictivas en el núcleo de las relaciones familiares, a saber, la sustracción de menores (art.225 bis CP) y la inducción al hijo menor a infringir el régimen de custodia (art. 224.2 CP), al tiempo que modificaba la falta contenida en el art. 622 (ya derogada), sin contar con otras modificaciones importantes en diversas ramas jurídicas, como la civil, donde se incluye una serie de medidas para evitar una posible sustracción parental.

El delito de sustracción de menores había sido suprimido en el Código Penal de 1995, una tradicional figura de la Codificación española que, durante décadas, se mantuvo en la legislación penal, si bien con unos elementos típicos diferentes a los actuales, dado que era una figura pensada fundamentalmente para terceras personas que sustraían a un menor de su entorno familiar, siendo que, en la actualidad, se trata de un delito especial que solo puede ser perpetrado por los progenitores y un círculo restringido de sujetos pertenecientes al ámbito familiar cercano del menor en cuestión. Esta figura delictiva fue incorporada al Código Penal por la mencionada reforma de 2002 como consecuencia de la necesidad de instauración de un tipo en el que poder ubicar las conductas de los padres que procedían a huir con sus hijos, alejándolo del otro progenitor, aun cuando también quedan incluidos los casos en los que ambos progenitores sustraen al hijo del centro público encargado de su custodia.

Por su parte, el art. 224 CP pasaba a incluir un segundo párrafo. Dicho artículo contenía, antes de la citada reforma, un solo apartado, que sancionaba la conducta de inducción a una persona menor de edad o discapacitada a abandonar el domicilio familiar o el lugar donde residiera con el beneplácito de sus padres, tutores o guardadores, una conducta donde se aprecia con claridad que el sujeto activo nunca podrían ser estos últimos, pues están configurados directamente como víctimas, como sujetos pasivos. Así las cosas, se procedió a incluir un segundo párrafo precisamente para el supuesto de que fuera el progenitor el inductor, no ya del abandono del hogar familiar, sino de la infracción del régimen de custodia, siendo que parte de la doctrina y la Jurisprudencia mayoritaria interpretan el término "custodia" de forma muy estricta, incluyendo solo la guarda y custodia, no así el régimen de visitas, por lo que tradicionalmente se ha venido entendiendo que el sujeto activo solo podía ser el progenitor no custodio. De esta forma, la gran mayoría de sentencias en las que se denuncia al progenitor custodio por infracción del régimen de visitas arbitran un fallo absolutorio a la luz de la interpretación de que dicho progenitor no puede verificar la conducta, sino que dicho comportamiento tenía mayor acomodo en la ya derogada falta contenida en el art.618 CP, habiendo sido el mismo despenalizado al no haber pasado a configurar un delito leve, bajo el prisma de que se integra mejor en otras ramas del Derecho, en este caso, la civil.

Mientras que la conducta de inducción al hijo menor a la infracción del régimen de custodia se incardinó, como acaba de mencionarse, en el segundo apartado del art. 224 $\mathrm{CP}$, es decir, en el Capítulo de los delitos contra los derechos y deberes familiares, concretamente en la primera sección, relativa al quebrantamiento de los deberes de custodia y de la inducción de menores al abandono del domicilio, el delito de sustracción de menores se ubicó en una sección aparte, en la sección segunda, que solo contiene el propio delito de sustracción de menores, para lo cual fue creado el artículo 225 bis. Resulta necesario destacar que, mientras que las diligencias previas abiertas han ido disminuyendo con los 
años, los delitos de quebrantamiento del régimen de custodia y de sustracción de menores han ido aumentando ${ }^{1}$.

A pesar de que ambas figuras se sitúan en ubicaciones diversas presentan una conexión mucho más íntima de lo que a priori parece, pues no solo tienen en común su pertenencia al conjunto de delitos contra las relaciones familiares, sino que podría decirse que una es continuación de la otra, quiere decirse, que se producirá un delito u otro dependiendo de la edad y características del menor en cuestión. De esta forma, la sustracción de menores se producirá cuando el menor sea de corta edad y la infracción del régimen de custodia acontecerá cuando el menor ya presente un concreto grado de madurez que le otorgue capacidad para ser inducido. En otras palabras, la intención del sujeto activo será, por regla general, la de permanecer con el menor, lo cual vulnerará los derechos derivados de la patria potestad o de custodia del otro progenitor o del custodio (en el caso de que el menor se encuentre a cargo de un tercero). Si el menor es de corta edad, esto se realizará mediante el traslado o la retención de aquel. De hecho, la edad media de un menor sustraído es de 6,4 años, resultado que se obtiene de la edad media de los niños sustraídos por la madre (6 años) y la edad media de los niños sustraídos por el padre $(7,2)^{2}$. Si el menor es ya adolescente, ese traslado o retención serán más difíciles, por motivos evidentes, por lo que en ese caso se optará por la manipulación de aquel para que sea él mismo quien infrinja el régimen de custodia. Además, también debe incluirse en el juego una tercera posibilidad, sin la cual el análisis de estos comportamientos quedaría irremediablemente incompleto: la posible atipicidad del comportamiento cuando es el menor con capacidad suficiente para decidir el que toma la decisión de irse a vivir con el otro progenitor, momento en el cual no existirá ni sustracción ni inducción. Para ello, será de vital importancia la eficacia del consentimiento.

\section{ANÁLISIS DE LA FIGURA CONTENIDA EN EL ART. 224.2 CP}

El art. 224 CP se integra en el Capítulo III del Título XII del Código Penal. Esto implica que forma parte de los delitos contra los derechos y deberes familiares. Concretamente, se sitúa en la primera sección, referida al quebrantamiento de los deberes de custodia y a la inducción de menores al abandono del domicilio.

El primer apartado del mencionado artículo castiga la inducción de una persona menor de edad o discapacitada al abandono del domicilio familiar o el lugar en el que reside con anuencia de sus padres o tutores. No obstante, a efectos del presente estudio, el párrafo que más interesa es precisamente el segundo, aquel que fue introducido por la LO 9/2002, junto con la figura de la sustracción de menores. Ese segundo párrafo sanciona con la misma pena del apartado anterior (pena de prisión de seis meses a dos años), al progenitor que induce al hijo menor a infringir el régimen de custodia que haya sido establecido por parte de la autoridad judicial o administrativa ${ }^{3}$.

1 ROCA AGAPITO, L. Tratado de Derecho Penal español, parte especial, II (Dir. ALVÁREZ GARCÍA, F.J.), Tirant lo blanch, Valencia, 2021, p. 1683.

2 OTAEGUI AIZPURUA, I. La eficacia de los derechos fundamentales de la UE: cuestiones avanzadas (dir. GOIZUETA VÉRTIZ, J. y CIENFUEGOS MATEO, M.), Thomson Reuters Aranzadi, Pamplona, 2014, p. 480.

3 La diferencia entre los dos párrafos del art. $224 \mathrm{CP}$ ha sido puesta de manifiesto por la Jurisprudencia, concretamente por el AAP Madrid, núm. 487/2006, de 8 de junio, en los siguientes términos: si en el primer párrafo parece claro 
Señala la doctrina que, en general, las figuras contenidas entre los arts. 223 y 233 poseen una dimensión mediata y otra inmediata, esto es, se protege de manera inmediata el conjunto de derechos y deberes que deben respetarse en el ámbito familiar, mientras que la tutela de la seguridad de los menores y las personas discapacitadas ligadas a la institución familiar sería el objeto de protección mediato ${ }^{4}$. También se ha concretado el bien jurídico protegido por este delito en los derechos del menor y el régimen de custodia legalmente establecido 5 . Por su parte, indica la Jurisprudencia que el interés tutelado es la seguridad del menor, entendida en el sentido de proporcionar al menor el contexto adecuado para su desarrollo psíquico y emocional, mediante el contacto con ambos progenitores ${ }^{6}$.

Realmente el tipo plantea algunos problemas de interpretación. Así, por ejemplo, lo primero que debería analizarse, con independencia de los conceptos de progenitor y de hijo menor, es el propio concepto de régimen de custodia, si es un concepto amplio, capaz de integrar tanto la guarda y custodia como el régimen de visitas o si, por el contrario, se trata de un concepto estricto, englobable únicamente a la primera, en cuyo caso, habría que obtener como conclusión que solo el progenitor no custodio es el posible sujeto activo del tipo. De cualquier forma, lo cierto es que el delito presenta una naturaleza de delito especial propio, por cuanto solo puede ser cometido por el progenitor, a diferencia de la conducta recogida en el primer párrafo, que se configura como un delito común. De hecho, se ha señalado que si el régimen de custodia es infringido por un tercero, la conducta habría de integrarse en el art. $223 \mathrm{CP}^{7}$.

Para respetar el orden de aparición de los distintos conceptos en la referida redacción típica, se comenzará aludiendo brevemente a los conceptos de progenitor e hijo menor de edad, explicación que servirá, asimismo, para el delito de sustracción de menores, donde dichos conceptos poseen el mismo significado.

En primer lugar cabe decir que, como destaca la doctrina y para no caer en interpretaciones ilógicas, debe entenderse por progenitor tanto el padre como la madre, sin que quepa inferir que el hecho de que el legislador haga referencia a "progenitor" deja fuera a la madre como posible sujeto activo de esta conducta, al igual que claramente el sujeto pasivo no puede quedar concretado en un hijo varón solamente por la razón de que el legislador se refiere a "hijo menor" y no a "hijo o hija menor", pues "es claro que el masculino de la redacción típica no impide que la madre pueda ser sujeto activo de este delito".

Yendo un paso más allá en relación con el término progenitor, puede atisbarse otro conflicto. Tradicionalmente, el progenitor se ha representado como la persona ligada al hijo

que se tipifica un comportamiento que puede crear un peligro relevante para el menor o incapaz (actualmente, persona discapacitada necesitada de especial protección) a quien se incita a abandonar el medio protegido en que se encuentra, en el segundo esta finalidad tutelar es menos evidente, prevaleciendo la desobediencia indirecta $u$ oblicua a lo dispuesto judicial o administrativamente

4 Olmedo CARDEnete, M. Sistema de Derecho Penal. Parte Especial (dir. MORILlAS CUEVA, L.), $4^{\mathrm{a}}$ ed., Dykinson, Madrid, 2021, p. 421.

5 FERNÁNDEZ BAUTISTA, S. Manual de Derecho Penal. Parte especial (dir. CORCOY BIDASOLO, M.), Tomo I, Tirant lo blanch, Valencia, 2019, p. 401.

6 AAP Barcelona, núm. 1508/2020, de 12 de noviembre.

7 OLMEDO CARDENETE, M. Sistema de..., Ob. cit., p. 424.

8 GUARDIOLA GARCÍA, J. "Los sujetos del delito previsto en el artículo 225 bis del Código Penal”, Secuestro de menores en el ámbito familiar: un estudio interdisciplinar (coord. LLORIA GARCÍA, P.), Iustel, Madrid, 2008, p. 93. Aunque este autor se refiere a estos conceptos en el seno del delito de sustracción de menores, cabe extrapolar las mismas conclusiones en el art. 224.2 CP debido a la estrecha relación que presentan. 
por un vínculo biológico, no así por un vínculo jurídico 9 . Esto supondría dejar fuera del tipo aquellos casos en los que el hijo menor sea adoptivo y no biológico, cosa que parece completamente inadmisible en los tiempos actuales ${ }^{10}$. Por este motivo, por progenitor debe entenderse tanto el padre como la madre, siendo indiferente el tipo de filiación existente ${ }^{11}$. Indudablemente, el legislador se quería referir al padre o a la madre, pero utilizó el término progenitor para englobar a ambos, sin que pueda interpretarse que los niños adoptados o provenientes de fecundación queden fuera de la protección penal ${ }^{12}$. Por consiguiente, cada vez que se utilice el término "progenitor", se hará referencia al padre o a la madre, en el sentido utilizado por el legislador, con independencia del tipo de filiación de que se trate, pues en ningún momento el tipo queda restringido a la filiación biológica ${ }^{13}$. Lo contrario, esto es, dejar fuera del ámbito de lo punible a los padres no biológicos no tendría sentido ${ }^{14}$. Incluso los padres que no estén ejerciendo la patria potestad podrían cometer esta conducta ${ }^{15}$.

En lo tocante al hijo menor de edad, ha de entenderse menor de dieciocho años, que es el momento en el que se alcanza la mayoría de edad. Sin embargo, ha de tenerse muy en cuenta que lo frecuente será que este delito sea aplicable durante el periodo de adolescencia del menor, toda vez que es una conducta que gira en torno a la inducción, por lo que el menor ha de poseer capacidad para ser inducido, algo que no será posible en menores de corta edad.

9 Para mayor profundidad sobre la diferencia entre la paternidad biológica y la jurídica, véase BENÍTEZ ORTÚZAR, I. F. Aspectos jurídico-penales de la reproducción asistida y la manipulación genética humana, Editoriales de Derecho Reunidas. EDERSA, Madrid, 1997.

10 La doctrina también aboga por no admitir distinciones entre padres biológicos y adoptivos. Así GUARDIOLA GARCÍA, J. afirma que "Progenitor es el pariente en línea recta ascendente, y ascendiente en el sentido del Código Penal se puede ser tanto por naturaleza como por adopción, de forma que si el precepto no distingue nec nos distinguere debemus; y mucho menos para alcanzar conclusiones profundamente insatisfactorias y dudosamente admisibles en clave constitucional. [...] Los ascendientes por naturaleza o adopción, en filiación matrimonial o extramatrimonial, entrarán, pues, en el ámbito típico". En "Los sujetos del delito...”, Ob. cit., p. 94. Por su parte, DÍEZ RIPOLLÉS, J. L., sostiene que "por progenitor habrá que entender a los padres biológicos o por naturaleza, matrimonial o no, así como a los padres por adopción, siempre que no sean los titulares de la guarda material de su hijo menor, siendo irrelevante que la tengan encomendada temporalmente". En "El nuevo delito de sustracción parental de menores", Estudios penales en recuerdo del Profesor Ruiz Antón (coord. DE TOLEDO y UBIETO, E. O.; GURDIEL SIERRA, M; y CORTÉS BECHIARELLI, E.), Tirant lo Blanch, Valencia, 2004, p. 292.

11 La Constitución es clara a la hora de otorgar protección a los hijos. Atrás quedaron los años en que solo quedaban protegidos los llamados "hijos legítimos", aquellos nacidos en el seno de un matrimonio, con la subsiguiente desprotección de los denominados "hijos bastardos". Superada tan anacrónica idea, la Constitución Española establece en su artículo 39.2 la protección integral de los hijos con independencia de su filiación. Por tanto, es indiferente si la filiación del niño es biológica o adoptiva, matrimonial o extramatrimonial, antes al contrario, será protegido en cualquier supuesto.

12 Aun cuando no parece realmente que el legislador haya cometido un error terminológico, dado que el Diccionario de la Real Academia Española define la palabra progenitor, si bien en su tercera acepción, como "el padre y la madre" y que debe concluirse que el delito de sustracción de menores puede perpetrarse cuando el hijo menor de edad es un hijo biológico, pero también cuando es adoptado o concebido mediante inseminación artificial, siempre y cuando el sustractor sea el padre o la madre, lo cierto es que la redacción no es la más acertada porque la palabra "progenitor" está dotada de un vínculo biológico que puede perfectamente no existir entre el sustractor y el sustraído, lo que acontecerá si el padre o la madre son adoptivos.

13 De la misma opinión, aunque refiriéndose al delito de sustracción de menores, LLORIA GARCÍA, P. "La regulación penal de las conductas sustractoras de menores en el ámbito familiar", Secuestro de menores en el ámbito familiar: un estudio interdisciplinar (coord. LLORIA GARCÍA, P.), Iustel, Madrid, 2008, pp. 44-45.

14 ROCA AGAPITO, L. Tratado de Derecho Penal..., Ob. cit., p. 1693.

15 Señala ROCA AGAPITO, L. el ejemplo de los padres que, por razón de maltrato, no ejercen la patria potestad de sus hijos y lo inducen a que abandone el domicilio de acogida en el que se encuentran. En Tratado de Derecho Penal..., Ob. cit., p. 1693. 
Una vez aclarados sendos conceptos, es el turno de introducirse en la cuestión principal del art. 224.2 CP. En realidad son dos las cuestiones cruciales del precepto: el propio concepto de régimen de custodia, de cuya amplitud dependerá la mayor o menor extensión del tipo; y el concepto de inducción, es más, la inducción a una persona menor de edad.

Comenzando con el asunto relativo al régimen de custodia, hemos de retrotraernos hasta el año 2015, momento en el cual desaparecen las faltas por medio de la reforma operada por la LO 1/2015, de 30 de marzo. En ese momento, algunas de las faltas fueron reubicadas a otras partes del Código reconvertidas en delitos leves y otras quedaron derogadas, quiere decirse, se procedió a la reubicación de ciertas conductas adoptando una nueva forma, la de delito leve, mientras que otras quedaron directamente despenalizadas.

En este sentido, antes de la desaparición de las faltas, existía una conducta que castigaba el incumplimiento leve del régimen de visitas, el ya derogado art. 618.2 CP. De igual manera, el antiguo art. $622 \mathrm{CP}$ preveía una sanción para los padres que procedieran a la infracción leve del régimen de custodia establecido para los hijos. Pues bien, como indica OLMEDO CARDENETE, la reforma de 2015 no introdujo ninguna disposición específica, ni siquiera en forma de delito leve, del incumplimiento de carácter leve de los regímenes de visitas, por lo que desde el momento en que se derogó tal precepto, dicha conducta es penalmente impune ${ }^{16}$. A esto se le suma la idea de que la infracción ocasional del régimen de visitas tampoco puede conformar un delito de desobediencia, que quedará reservado para cuando se produzca una desatención reiterada de los correspondientes requerimientos judiciales tendentes a su cumplimiento ${ }^{17}$.

La Jurisprudencia secundaba esta interpretación. De hecho, el criterio jurisprudencial hace hincapié en que el artículo 618.2 era aplicable en el caso de que lo que se incumpliera fuese el régimen de visitas, algo que podía provenir por el comportamiento del custodio o del no custodio ${ }^{18}$. Por el contrario, si lo que se incumplía era el régimen de custodia, la conducta debía ser dirimida a través de la falta del artículo 622, por lo que el sujeto activo en este caso solo podía ser el progenitor no custodio ${ }^{19}$. Es decir, infringir el régimen de visitas e infringir el régimen de custodia son dos cosas bien distintas ${ }^{20}$.

16 OLMEDO CARDENETE, M. Sistema de..., Ob. cit., p. 410.

17 Ibidem, p. 410.

18 De hecho, la SAP Sevilla núm. 11/2004, de 12 de enero, expone muy bien por qué una conducta consistente en no entregar al hijo en cumplimiento de un régimen de visitas no podía insertarse en el derogado artículo 622 del Código Penal: porque dicha falta castiga el quebrantamiento de la resolución judicial o administrativa por la que se atribuye la guarda y custodia del menor a una persona, familia o institución tutelar; pero no está pensada para sancionar el simple incumplimiento concreto y delimitado del régimen de visitas que en esa resolución se haya podido establecer. [...] En otras palabras: el progenitor que se empeña en ejercer su derecho de visita un día que no le corresponde, como el que impide al otro ejercerlo el día establecido, o el que prolonga más allá de lo convenido su estancia con el hijo común no cometen la infracción que nos ocupa, pues no quebrantan la guarda y custodia del menor, aunque todos ellos incurran en un incumplimiento o contravención del régimen de visitas establecido o aprobado judicialmente.

19 Así, la SAP Valencia núm. 101/2000, de 15 de febrero, condena por la antigua falta del artículo 622 del Código Penal en el caso de una pareja separada que por convenio acuerda otorgar la guarda y custodia del menor a la madre, adjudicándose al padre un régimen de visitas en fines de semanas alternos. El padre decidió recoger al menor del centro escolar en un día que no le correspondía y sin aviso ni consentimiento de la madre, de forma que cuando el tío del menor (autorizado por la madre) se presentó en el colegio para recoger al niño, se le informó de que este ya había sido recogido por el padre, que procedió a reintegrar al hijo al día siguiente a dicho centro. Fue condenado en juicio de faltas a la pena de un mes de multa, sentencia confirmada por la Audiencia Provincial de Valencia.

20 La Audiencia Provincial de Sevilla distingue muy bien ambos términos y así lo expresa en la Sentencia número 11/2004, de 12 de enero: El derecho de visita es la contrapartida que, en interés del menor, corresponde al cónyuge privado de la guarda y custodia de sus hijos para conservar el contacto con estos. El régimen de visitas 
Deben destacarse, igualmente, los motivos que llevaron al legislador tanto a la creación de la falta como a su despenalización, de forma que ello nos arroje algo de luz acerca del concreto contenido que debe aportarse al término "régimen de custodia". En el caso del art. $618 \mathrm{CP}$, la introducción de un segundo apartado obedeció al deseo de tipificar conductas de ínfima gravedad relacionadas con el incumplimiento de un convenio judicialmente aprobado o una resolución judicial ${ }^{21}$. En el momento de su derogación, la LO 1/2015 incluyó una motivación para tal despenalización, aludiendo a la desaparición no solo de este precepto, sino también del art. $622 \mathrm{CP}$, justificando que dichas derogaciones obedecen a que las conductas más graves ya estaban previstas como delitos contra las relaciones familiares, siendo que los incumplimientos más graves podían dar lugar al genérico delito de desobediencia, dejando el resto de conductas de menor gravedad a cargo del régimen sancionador del art. $776 \mathrm{LEC}$, que se refiere expresamente al incumplimiento del régimen de visitas ${ }^{22}$. En este sentido, ha de precisarse que la mencionada Ley Orgánica deriva al régimen sancionador de la LEC los comportamientos que no poseen la gravedad suficiente, siendo que lo que explica el art. 776 de dicho cuerpo normativo no es otra cosa que el hecho de poder modificarse el régimen de visitas si este se incumple de manera reiterada. Para los casos de mayor gravedad, siempre quedarán los delitos de desobediencia. Ello nos aporta una pista más en la búsqueda de respuestas: la despenalización del art. 618.2 CP ha sido derivada a la legislación civil solo cuando el comportamiento no presenta entidad suficiente, reservándose la vía penal para los supuestos más graves. Ahora bien, pese a que la LO 1/2015 refleja que la adecuada solución sería el delito de desobediencia, momento en el que se percibe que la puerta del Derecho penal sigue quedando abierta para castigar los supuestos de mayor gravedad, ha de analizarse si el delito más adecuado es verdaderamente el delito de desobediencia o si, por el contrario, entraría más bien en el art. $224 \mathrm{CP}$, cuando exista inducción sobre el menor, planteándose así un concurso de normas. Nuevamente, todo depende del concepto más o menos amplio que se aporte de régimen de custodia, inclusive o no del derecho de visitas.

En este sentido, hay quien señala que el autor de este delito puede ser cualquiera de los progenitores, tanto el que tiene atribuido el régimen de custodia como el que posee el derecho de visitas, lo que en ambos casos conllevaría la infracción a la que el tipo se refiere ${ }^{23}$.

Por el contrario, otra postura mantiene que el régimen de custodia alude al incumplimiento grave del contenido de una resolución judicial o administrativa en lo referente a la guarda y custodia, pero no al régimen de visitas ${ }^{24}$. Por consiguiente, el sujeto activo

no es una de las facultades inherentes a la guarda y custodia, sino la consecuencia de la necesaria exclusión de éstas de uno de los progenitores protagonistas de la ruptura. El cónyuge que tiene atribuida la custodia de los hijos puede infringir el régimen de visitas, pero no el de custodia, cuya infracción solo es posible, salvo supuesto anómalos, por el progenitor apartado de la convivencia con los hijos.

21 En concreto, expresa que los delitos de incumplimiento de obligaciones derivadas de los convenios judicialmente aprobados o resoluciones judiciales en los supuestos de separación legal, divorcio, declaración de nulidad del matrimonio, proceso de filiación o proceso de alimentos a favor de los hijos se mantienen y se incorpora una falta para el caso de las conductas de ínfima gravedad, en este último caso incluyendo cualquier incumplimiento de obligaciones no sólo aquellas que tengan contenido económico.

22 Este precepto determina en su tercer apartado lo siguiente: El incumplimiento reiterado de las obligaciones derivadas del régimen de visitas, tanto por parte del progenitor guardador como del no guardador, podrá dar lugar a la modificación por el Tribunal del régimen de guarda y visitas.

23 FERNÁNDEZ BAUTISTA, S. Manual de..., Ob. cit., p. 401.

24 ROCA AGAPITO, L. Tratado de Derecho Penal..., Ob. Cit., p. 1697. 
solo podría ser el progenitor al que no se le haya atribuido la custodia ${ }^{25}$. Este parece ser también el sentir de la Jurisprudencia ${ }^{26}$, lo cual ha servido para negar la responsabilidad penal del progenitor cuando este era el custodio y había sido acusado por infringir el régimen de comunicación ${ }^{27}$. En estos casos, se alude a la utilización del art. 775 LEC, quiere decirse, a la solicitud de la modificación de medidas ${ }^{28}$.

En línea parecida, se ha negado la posibilidad de comisión del tipo por parte de los progenitores si ambos gozan del régimen de custodia compartida, siendo que solo podría cometer el delito el que no disponga de la guarda y custodia en los casos en que esta no sea compartida ${ }^{29}$.

Tiene razón el sector doctrinal que interpreta el término "régimen de custodia" en sentido amplio, incluyendo el régimen de visitas, resultando por tanto que el menor puede ser inducido por el padre custodio a incumplir el régimen de comunicación ${ }^{30}$. Por ende, sujeto activo será cualquiera de los progenitores, con independencia de si dispone de la guarda y custodia o de un régimen de visitas y, por supuesto, también en los casos de custodia compartida.

A la luz de la reforma operada por la LO 8/2021, de 4 de junio, que modifica el art. 225 bis CP relativo a la sustracción de menores en el sentido de que ambos padres puedan cometer el tipo, con independencia de si son custodios o no, lo cierto es que ambas figuras deben ser interpretadas en términos similares, dada la evidente relación que presentan entre sí. Aunque este extremo será explicado más detalladamente en el último punto de este escrito, puede ahora adelantarse que lo que distingue una conducta de otra es, fundamentalmente, la edad del menor. Así, si el niño es de corta edad, no presenta capacidad de decisión, el sujeto activo podrá sustraerlo por sí mismo, trasladándolo o reteniéndolo ilícitamente. Por el contrario, durante la época de la adolescencia, será más difícil ese traslado o retención, sobre todo por las capacidades de resistencia que presentará, por lo que el comportamiento típico pasará por convencer o instigar al menor a que sea él mismo quien se sustraiga al régimen establecido. Si la decisión es libre, la conducta es atípica.

25 Serrano tÁrraga, Ma . D. Curso de Derecho Penal. Parte Especial, $5^{\text {a }}$ ed., Dykinson, Madrid, 2019, p. 269 y RODRÍGUEZ NÚÑEZ, A. Delitos. La parte especial del Derecho penal (coord. LAMARCA PÉREZ, C.), $4^{\mathrm{a} e d .}$, Dykinson, Madrid, 2019, p. 300.

26 Así, por ejemplo, la AAP Barcelona, núm. 641/2020, de 18 de junio, explica: en el delito previsto en el art. 224.2 $C P$, se castiga al progenitor que induzca a su hijo menor a infringir el régimen de custodia establecido por la autoridad judicial o administrativa, conducta que debe ponerse en relación con el párrafo primero, es decir, el sujeto activo sería en principio el padre o madre no custodio por resolución judicial o administrativa, que tiene reconocido solo un régimen de visitas por una decisión judicial en materia de familia que ha otorgado la guarda o custodia al otro progenitor.

27 Así se determina en distintas resoluciones judiciales, como en el AAP La Rioja, núm. 27/2018, de 30 de enero; el AAP La Rioja, núm. 116/2018, de 22 de marzo; la SJP Murcia, núm. 143/2018, de 8 de mayo; la SAP A Coruña, núm. 236/2017, de 24 de mayo; el AAP Valencia, núm. 309/2019, de 25 de marzo; o el AAP Pontevedra, núm. 121/2021, de 26 de febrero, que expresa que en dicho asunto, es la progenitora quien ostenta la custodia de los menores y el "adoctrinamiento" en contra de su padre que se le achaca en la denuncia, no conforma una inducción a la quiebra de un régimen de custodia que ella misma tiene atribuido.

28 Así, por ejemplo, el AAP La Rioja, núm. 374/2018, de 13 de julio.

29 TERRADILlOS BASOCO, J. M. - GONZÁLEZ AGUDELO, G. Lecciones y materiales para el estudio del Derecho Penal (coord. TERRADILLOS BASOCO, J. M.), Tomo III, vol. I, 2a ed., Iustel, Madrid, 2016, p. 355.

30 Idea secundada por TORRES FERNÁNDEZ Ma. E. "Los nuevos delitos de secuestro parental e inducción de hijos menores al incumplimiento del régimen de custodia", La Ley: Revista jurídica española de doctrina, jurisprudencia y bibliografía, núm. 4, 2003, p. 1823. 
Dado que ninguno de los titulares de la patria potestad posee más derechos que el otro y en vista de que ambas figuras protegen el mismo bien jurídico y presentan los mismos sujetos activos, lo cierto es que resulta adecuado que se realice una interpretación amplia del tipo. Pese a poder encuadrar la conducta de la infracción al régimen de visitas en el genérico delito de desobediencia, resulta más apropiado ubicarlo en este tipo penal al constituir un comportamiento que atenta contra las relaciones familiares, concretamente sobre los derechos derivados del ejercicio de la patria potestad. Se trata de considerar que ambos titulares poseen igualdad de derechos y abandonar esa vieja idea de que el custodio es el que necesita mayor protección, siendo que ambas formas (custodia y régimen de comunicación) son dos maneras de ejercer la responsabilidad parental. Es por ello por lo que también habría sido deseable que el legislador incluyera una excusa absolutoria específica, tal y como se hace en el delito de sustracción de menores, en lugar de dejar el art. 224.2 CP supeditado al tipo atenuado establecido en el art. $225 \mathrm{CP}$, al que me referiré infra, dado que este último parece integrar supuestos en que son terceras personas distintas a los titulares de la patria potestad los que llevan a cabo las distintas figuras delictivas.

Por su parte, el sujeto pasivo es el titular del derecho de custodia y no el menor, que solo es el inducido a realizar un hecho atípico ${ }^{31}$. Otras posturas abogan por incluir al propio menor como sujeto pasivo del delito, junto con los padres o la persona que detenta la custodia ${ }^{32}$.

En lo tocante a la inducción, se ha apuntado que en esta figura ha de entenderse no en un sentido técnico de inducción como forma de autoría, sino en una genérica acepción de incitación a observar una determinada acción no subsumible en un tipo legal ${ }^{33}$. Sin embargo, expone la Jurisprudencia que inducir es una forma de participación llevada a la categoría de autoría; la voluntad del menor se presume débil en atención a su propia condición y está captada por los ardides o artificios del agente ${ }^{34}$.

Esta ha de ser eficaz ${ }^{35}$, habiendo manifestado también la Jurisprudencia que la inducción ha de ser una acción directa, concreta y eficaz enderezada a hacer surgir en otro la voluntad, hasta entonces inexistente, de realizar un hecho concreto ${ }^{36}$. Por lo tanto, no sería típico el mero consejo o la recomendación ${ }^{37}$, ni tampoco las expresiones que se limiten a alentar una decisión ya previamente tomada ${ }^{38}$. La conducta típica consistiría en hacer surgir en otro la voluntad de infringir el régimen de custodia ${ }^{39}$.

Por consiguiente, el comportamiento es atípico cuando no existe inducción, quiere decirse, cuando el menor infringe el régimen de custodia por sí mismo, sin una previa

31 De la misma opinión, SERRANO TÁRRAGA, Ma. D. Curso de Derecho Penal..., Ob. cit., p. 269.

32 Así, por ejemplo, RODRÍGUEZ NÚÑEZ, A. Delitos. La parte especial..., Ob. cit., p. 300.

33 POlaino NAVARrete, M. Lecciones de Derecho Penal, Parte Especial (dir. POLAINO NAVARRETE, M.), $2^{\mathrm{a}}$ ed., Tomo I, Tecnos, Madrid, 2019, p. 383.

34 AAP Cáceres, núm. 28/2009, de 29 de enero.

35 RUBIO LARA, P. A. Manual teórico de Derecho Penal II. Parte Especial del Derecho Penal, Tirant lo blanch, Valencia, 2017, p. 109.

36 AAP Barcelona, núm. 470/2019, de 2 de octubre. De la misma opinión, por ejemplo, el AAP Madrid, núm. $773 / 2009$, de 29 de septiembre. En contra, indicando la falta de eficacia de la inducción, es decir, interpretando que el tipo no exige que el inductor consiga su propósito, el AAP Madrid, núm. 487/2006, de 8 de junio.

37 MUÑOZ CONDE, F. Derecho Penal. Parte Especial, 22a ed., Tirant lo blanch, Valencia, 2019, p. 303.

38 MOLINA FERNÁNDEZ, F. Memento Práctico (coord. MOLINA FERNÁNDEZ, F.), Francis Lefebvre, Madrid, 2021, p. 1251.

39 ROCA AGAPITO, L. Tratado de Derecho Penal..., Ob. Cit., p. 1695. 
instigación. Esta es también la idea reflejada por la Jurisprudencia. Así, la Audiencia Provincial de Madrid determina que la perito que explora a una menor que abandona el domicilio de la madre custodia para irse a vivir con su padre concluye que no ha habido manipulación alguna por parte de aquel, presentando la menor una claridad cognoscitiva para decidir por sí misma, no habiéndose dejado influenciar por el padre ni siquiera de manera sutil ${ }^{40}$.

A la misma conclusión, llega la Audiencia Provincial de Salamanca, en un caso en el que dos menores de edad que residían con su madre, se dirigen a la salida del colegio al domicilio de su padre, con ánimo de permanencia. El padre pone estos hechos en conocimiento de la Guardia Civil, que mantienen una conversación con ambas menores, indicando ellas que no quieren volver con su madre, sino permanecer con su padre, deduciéndose del atestado policial que es una decisión tomada voluntariamente. Así las cosas, la Audiencia desestima el recurso de apelación presentado por la madre ${ }^{41}$.

Por tanto, la inducción consistiría en instigar, persuadir o mover a alguien a hacer alguna cosa, sea objetivamente eficaz en el esfuerzo del autor por convencer al menor de edad de que se ausente del espacio natural donde encuentra su referente protector y afectivo y donde son menos intensos los riesgos que le puedan acechar, siendo atípica la conducta cuando el menor demuestra tener capacidad de autodeterminación ${ }^{42}$.

En definitiva, la inducción ha de ser determinante, porque ha de hacer surgir en el menor la resolución de infringir el régimen de custodia, lo cual no será posible si dicho menor carece de capacidad de juicio; eficaz; dolosa, por no haberse previsto una modalidad imprudente; y activa, sin que quepa admitir supuestos de comisión por omisión ${ }^{43}$.

Es necesario reseñar, aun cuando esto pudiera parecer una obviedad, que el tipo castiga la inducción del régimen de custodia, no la falta de favorecimiento del mismo, lo que llevó a la Audiencia Provincial de Tarragona a determinar la atipicidad del comportamiento de una madre que incumple el deber de entregar la hija al padre, acusada porque no favoreció ni convenció a aquella para que se marchara voluntariamente con su progenitor ${ }^{44}$.

Por otra parte, no ha de confundirse, como no puede ser de otra manera, la inducción con el amparo, esto es, no puede calificarse de inducción a la conducta de un progenitor que se limita a otorgar amparo al hijo menor de edad que ha abandonado el domicilio habitual y así lo ha indicado expresamente la Audiencia Provincial de Pontevedra,

40 AAP Madrid, núm. 862/2008, de 2 de septiembre.

41 El AAP Salamanca, núm. 181/2020, de 5 de junio, se expresa en los siguientes términos: Inducir es determinar consciente e intencionadamente a otra persona a adoptar un determinado comportamiento, esto es, sería la persuasión, incitación, convencimiento o manipulación de una persona, en este caso de la menor, para la infracción del régimen de custodia, o la presión psicológica sobre ella por parte del sujeto activo para que adopte una decisión que no responde a su libre voluntad, sino a la situación de preeminencia moral o de otra índole del sujeto activo. Esta fundamentación fue rescatada de una Sentencia del propio Tribunal Supremo, de 20 de octubre de 2005. Esta misma argumentación fue recogida por el AAP Jaén, núm. 291/2019, de 29 de mayo, que determina la atipicidad de la conducta de la menor que no quiere irse con su padre porque no se apreció a la madre una actuación de inducción hacia su hija, sino que fue esta última la que decidió voluntariamente no irse con el padre. AAP Madrid, núm. 723/2015, de 28 de octubre.

43 ROCA AGAPITO, L. Tratado de Derecho Penal..., Ob. Cit., p. 1696.

44 Los AAP Tarragona, núm. 344/2019, de 10 de junio y AAP Tarragona, núm. 663/2019, de 10 de diciembre expresan la siguiente idea: el tipo no castiga la falta de voluntad positiva o promocional del progenitor para que el menor cumpla el régimen de custodia, sino aquellas conductas que en términos normativos puedan calificarse de inductivas para que el menor no los cumpla. 
en un supuesto de una menor de 13 años que se va de casa de su madre voluntariamente y acude a casa del padre. La resolución indica que no cabe extraer de las pruebas practicadas una conducta inductora del padre con respecto a la hija, sino que es esta la que se niega a volver con su madre, a la que además había denunciado por malos tratos, por lo que la Audiencia aprecia la inexistencia del delito ${ }^{45}$.

La edad del menor juega un papel crucial. En este sentido, se ha señalado que si el hijo o la hija es suficiente mayor es posible que se otorgue relevancia a su voluntad y quepa considerar que se trata de una conducta adecuada, aunque no se cuente con el consentimiento del otro progenitor ${ }^{46}$. También la Jurisprudencia se ha valido de la edad del menor para determinar la atipicidad de la conducta. Así, la Audiencia Provincial de La Rioja enfatiza en la cercanía del menor a la mayoría de edad en un supuesto en el que aquel decide marcharse de casa de su madre debido a los conflictos que tenía con ella, pasando a convivir con su padre ${ }^{47}$.

En similares términos, la Audiencia Provincial de Tarragona alude a la edad de la menor en un caso en el que es ella la que decide dejar de vivir con su padre, incidiendo en los dos elementos clave que le lleva a la resolución de desestimación del recurso de apelación: el primero era la conducta obstativa de la menor a someterse al plan de custodia fijado y el segundo era la edad de esta, quince años, pues en todas las exploraciones que se le habían hecho había quedado constatada su firme decisión de dejar de vivir con su padre ${ }^{48}$.

En definitiva, no puede existir responsabilidad penal al amparo del art. 224.2 CP cuando el menor está actuando siguiendo su libre voluntad ni cuando dicha decisión de abandonar el domicilio habitual sea una decisión ya tomada, por cuanto, en esos casos no habrá instigación ni inducción alguna ${ }^{49}$, es decir, cuando el ánimo de los menores ya estaba predispuesto a la infracción ${ }^{50}$, si bien es cierto que no solo la opinión de aquellos es la que cuenta, toda vez que son los padres los que tienen el derecho a fijar la residencia de sus hijos menores ${ }^{51}$.

45 El AAP Pontevedra, núm. 259/2021, de 16 de abril se expresa de la siguiente manera: en la permanencia de la menor con su padre no presenta en este momento caracteres de delito, dado que no puede atribuirse a la investigada conducta de inducción o de retención de la menor, sino de amparo a la voluntad de su hija que es quien, ya con trece años y en base a la difícil convivencia y conflictiva relación con la madre, se niega a volver con ella.

46 ROCA AGAPITO, L. Tratado de Derecho Penal..., Ob. Cit., p. 1694.

47 Así, el AAP La Rioja, núm. 132/2018, de 12 de abril afirma afirma que no debe obviarse que el menor tenía ya 17 años cuando tomó tal decisión y, por tanto, su grado de madurez y de discernimiento deben reputarse suficientes para elegir de forma sopesada y no caprichosa al progenitor con el cual deseaba convivir. El hecho de que el padre no realizara conducta activa alguna tendente a convencer a su hijo para regresar al domicilio materno no puede integrar en este supuesto una inducción por omisión pues a escasos a 3 meses de cumplir los 18 años el padre no puede imponer su voluntad sobre la de su hijo cuando este, además, tiene motivos justificados para irse a vivir con el progenitor no custodio.

48 AAP Tarragona, núm. 344/2019, de 10 de junio. En dicha resolución, la Audiencia Provincial arroja ideas tan relevantes como la siguiente: No afirmamos que deba en todo caso prevalecer la voluntad de la menor con relación a con quién o dónde debe vivir. Iría en contra del propio sentido del régimen de custodia y, muy probablemente, de su propio interés superior a recibir la protección y la asistencia material y afectiva necesaria para su adecuado desarrollo. Pero de ahi no cabe concluir, en los términos casi silogísticos de consecuencias necesarias que se sugieren en el recurso, que si la menor rechaza el contacto parental debe atribuirse a la inducción a la que es sometida por el propio progenitor.

49 Así, también, el AAP Navarra, núm. 190/2017, de 25 de mayo; el AAP Zaragoza, núm. 788/2017, de 27 de octubre; el AAP Jaén, núm. 116/2018, de 15 de febrero.

50 AAP La Rioja, núm. 311/2020, de 12 de junio.

51 Dato recalcado por el AAP Barcelona, núm. 294/2017, de 18 de abril. 
Incluso se ha observado el indicio de ausencia de inducción cuando el propio custodio no ha podido convencer a los hijos menores de que vuelvan a la casa donde convivían antes de marcharse, pues esto demuestra que no son influenciables, sino que han tomado la decisión voluntariamente ${ }^{52}$.

Distintos son los supuestos en los que el progenitor sí realiza actos encaminados a la persuasión del hijo a la infracción del régimen de custodia, como ocurrió en un caso resuelto por la Audiencia Provincial de Guipúzcoa en el que se acuerda la adopción de la medida cautelar de prisión provisional para un padre que había estado en contacto con la hija menor que se encontraba en un centro, del cual desaparece, siendo encontradas algunas conversaciones entre padre e hija en las que el primero instaba a la segunda a escaparse de dicho centro ${ }^{53}$. Justamente lo contrario ocurrió en otro supuesto similar resuelto por la misma Audiencia Provincial, en el que una menor se fugó del centro en el que se encontraba y fue ella misma la que contactó con su padre, que se limitó a prestar la ayuda que su hija le solicitó una vez estaba fuera de aquel. Además, la menor no disponía de teléfono móvil, por lo que no podía emitir ni recibir ningún mensaje, habiendo demostrado las pruebas que fue ella quien no deseaba seguir bajo la tutela de la Diputación y llegando a ser internada en un centro hospitalario tras su localización por su reincorporación al organismo público y la imposibilidad de permanecer junto a su padre, denegándose así la petición de prisión provisional para aquel ${ }^{54}$.

En otro orden de cosas, el delito se consuma cuando se realiza la inducción y se inicia, al menos, la ejecución de la infracción del régimen de custodia. Por consiguiente, si el menor logra ser inducido pero la infracción del régimen de custodia no acontece, no se inicia, el delito quedaría en grado de tentativa.

Como apunte final, ha de destacarse que existe un tipo atenuado en el art. 225 $\mathrm{CP}$, previsto para la comisión de los delitos tipificados en los arts. 223 y $224 \mathrm{CP}$, no aplicable, por ende, al delito de sustracción de menores, cuya tipificación aparece en el artículo inmediatamente posterior. No obstante, esta última figura presenta una excusa absolutoria propia, concretamente en el apartado cuarto del precepto. Pues bien, el art. $225 \mathrm{CP}$ rebaja la pena, que quedaría en prisión de tres meses a un año o multa de seis a 24 meses $^{55}$, si se restituye a la persona menor de edad o discapacitada a su domicilio o residencia o se le deposita en un lugar conocido y seguro sin haberle causado ningún daño ni haber puesto en peligro su vida, salud, integridad física o libertad sexual y siempre y cuando se haya comunicado a los padres, tutores o guardadores el lugar de estancia o la ausencia hubiese sido inferior a 24 horas. No obstante, este tipo atenuado parece más bien pensado para aquellos casos en los que el progenitor no es el sujeto activo del delito, lo cual no obsta para que, cumplidos todos los requisitos, resulte aplicable a la figura que se viene estudiando.

52 Así, señala el AAP Madrid, núm. 446/2010, de 23 de julio: Si la propia denunciante (después de dos horas de conversación con los menores), no tiene posibilidad de convencer a sus hijos para que permanezcan con ella, dificilmente puede atribuirse al denunciado un comportamiento intencionalmente dirigido a obstaculizar lo acordado respecto al régimen de guardia y custodia de los menores, partiendo de la decidida voluntad de estos, que cuentan con 16 y 14 años.

53 AAP Guipúzcoa, núm. 6/2019, de 14 de enero.

54 AAP Guipúzcoa, núm. 28/2019, de 18 de enero.

55 La pena prevista para el art. 224 CP es de prisión de seis meses a dos años. 


\section{ANÁLISIS DE LA FIGURA CONTENIDA EN EL ART. 225 BIS CP}

El art. 225 bis CP castiga al progenitor que sin causa justificada sustrajera al hijo menor con una pena de prisión de dos a cuatro años e inhabilitación especial para el ejercicio del derecho de patria potestad de cuatro a diez años, aplicándose también el tipo a ciertos parientes próximos (ascendientes del menor y parientes del progenitor hasta el segundo grado de consanguinidad o afinidad) enumerados en la cláusula extensiva del apartado quinto. A continuación, el legislador aporta un concepto de sustracción, pudiendo esta quedar concretada de dos maneras diferentes: o bien mediante el traslado del menor del lugar de residencia habitual o bien mediante la retención del mismo, siempre y cuando en este último caso, se incumpla de forma grave una resolución judicial o administrativa.

El bien jurídico protegido por este delito no es, pese a la intención inicial del legislador, los derechos del menor, sino los derechos del otro progenitor o de la persona encargada de su custodia, en tanto se trata de una conducta que ha de realizarse sin el consentimiento de estos. A este propósito, ha de destacarse la reciente modificación que ha sufrido este comportamiento. Así, por primera vez desde que fue creado allá por el año 2002, el delito ha sido modificado por la LO 8/2021, de 4 de junio, de protección integral a la infancia y a la adolescencia frente a la violencia. Se trata de una reforma muy positiva, a la par que necesaria, pues permite incluir en el tipo infinidad de supuestos que antes eran considerados atípicos, fruto de una legislación descuidada y poco rigurosa, con una Exposición de Motivos conflictiva que no hacía más que agravar la desafiante tarea de interpretar la norma y, lo que era más, colocarla en una situación de coherencia sistemática con el propio articulado. Tanto es así que incluso el Tribunal Supremo acabó concluyendo que dicha Exposición de Motivos había sido incorporada ex post por alguien que no había intervenido en la redacción de las modalidades delictivas ${ }^{56}$.

Pues bien, antes de la reforma de 2021, la doctrina y la Jurisprudencia mayoritarias entendían que el progenitor custodio no podía verificar la conducta, en tanto la modalidad de traslado rezaba que dicho traslado era delictivo siempre y cuando no contase con el consentimiento del progenitor que convivía habitualmente con el menor o de la persona encargada de su custodia. Ello suponía que, cuando en un proceso judicial, la custodia había sido atribuida a uno de los progenitores, el otro no podía trasladar al menor sin autorización de aquel, siendo únicamente el custodio el facultado para decidir.

Esta redacción típica ya es de por sí cuestionable, pues implicaba una protección parcial del bien jurídico protegido, atribuyendo más derechos a un progenitor que a otro simplemente por el modo de ejercicio de la responsabilidad parental. Por consiguiente, el progenitor custodio nunca ha gozado de un mayor poder o de mayores derechos que el no custodio. Por este motivo se insiste en la idea de que no debe confundirse poder de decisión con guarda y custodia, pues el poder de decisión entraría dentro del ejercicio de la patria potestad mientras que la guarda y custodia haría referencia a las funciones que han de encomendarse necesariamente al padre conviviente con el hijo para que puedan ser desarrolladas correctamente ${ }^{57}$. En definitiva, es necesario incidir en la idea de que el mero cese de convivencia no altera el ejercicio de la patria potestad más allá del tiempo

56 STS 339/2021, de 23 de abril.

57 GARCÍA PASTOR, M. La situación jurídica de los hijos cuyos padres no conviven: aspectos personales, McGrawHill, Madrid, 1997, p. 75. 
de compañía de los menores, toda vez que, lógicamente, el progenitor que tenga atribuido un régimen de visitas disfrutará de un tiempo menor, siendo que la custodia no otorga más derechos sobre el niño ${ }^{58}$.

Esta idea no solo ha sido puesta de manifiesto por la doctrina, sino también por la Jurisprudencia, como lo indica la Audiencia Provincial de Islas Baleares ${ }^{59}$ en el caso de una madre que, ostentando la guarda y custodia de su hijo, decide trasladarlo desde Mallorca hasta la República Checa en mitad del curso escolar, siendo su intención no volver a España aun cuando utilizó como pretexto que se iban de vacaciones. En estas circunstancias, la Audiencia Provincial observa una extralimitación del derecho de guarda y custodia y del ejercicio de la patria potestad porque la conducta de la madre estaba vulnerando los derechos del padre, que contaba con un régimen de visitas y vacaciones esporádicas, siendo que aquel no había prestado su consentimiento al traslado. La Audiencia enfatiza en la idea de que el padre y la madre tienen el mismo derecho a decidir el lugar de residencia habitual del menor y acaba atribuyendo la guarda y custodia del menor a aquel como consecuencia de esa extralimitación de esta, arrojando incluso el dato de que podría existir sustracción internacional en los términos previstos por el Reglamento $2201 / 2003$, que asume el hecho de que la custodia se ejerce de forma conjunta cuando uno de los titulares de la responsabilidad parental no puede decidir unilateralmente el lugar de residencia del menor ${ }^{60}$.

En el año 2015, la Fiscalía General del Estado emitió la Circular 6/2015, en la que se exponía claramente que los progenitores tienen la misma capacidad de decisión en asuntos relevantes, con independencia de a quién haya sido atribuida la guarda y custodia, dentro de los cuales, se incluye expresamente la decisión atinente al lugar de residencia habitual del menor ${ }^{61}$.

Por consiguiente, la figura de sustracción de menores nació en el año 2002 pero fue quedándose desfasada porque estipulaba una serie de derechos sobre el progenitor custodio que no se correspondía con la realidad legislativa, doctrinal y jurisprudencial. Ciertamente, el tipo fue creado en un momento en el que el paradigma de sustracción era el progenitor no custodio que aprovechaba el régimen de visitas para no devolver al me-

58 GARCÍA RIVAS, F.J. "Guarda y custodia compartida: la Ley 15/2005 de 8 de julio de reforma del Código Civil”, Revista jurídica de la Región de Murcia, núm. 37, 2006, p. 80.

59 SAP Islas Baleares núm. 294/2010, de 28 de julio.

60 Incluso el Tribunal Constitucional se ha posicionado a favor de esta postura desde antiguo. Así, en una de sus resoluciones (ATC núm. 127/1986, de 12 de febrero) y en cierta relación con la sustracción de menores, el Tribunal Constitucional denegó el amparo solicitado por una mujer de nacionalidad francesa que consideraba que la Audiencia Territorial de Valencia, en la Sentencia de 9 de julio de 1985, le había coartado su derecho a la libre residencia al haberle otorgado la guarda y custodia de sus hijas solo si decidía residir en España, no así en el caso de que se decantase por volverse a Francia, en cuyo caso, la guarda y custodia pasaría al padre. El Tribunal Constitucional denegó el amparo al entender que la Audiencia había tomado su decisión pensando en el interés de las menores, que consistía en permanecer en el ambiente en el que se encontraban.

61 En estos términos se expresaba la Fiscalía General del Estado en la Circular 6/2015, de aspectos civiles de la sustracción internacional de menores: si la sentencia de separación, nulidad o divorcio atribuye la guarda y custodia a un progenitor correspondiendo el ejercicio de la patria potestad a ambos, ambos tendrán que decidir sobre los asuntos de mayor trascendencia relativos a la vida y gobierno del menor. Por ello, en estos casos debe haber acuerdo de los dos progenitores ante cualquier modificación de la residencia del menor que suponga un cambio de su entorno físico y social. Por tanto, cuando se dicta una resolución estándar en la que, atribuyéndose la patria potestad conjunta y la guarda y custodia a uno de los progenitores, no se hace ningún pronunciamiento en cuanto a la facultad de decidir la residencia, la misma ha de entenderse corresponde a ambos progenitores de común acuerdo y, en su defecto, a la decisión judicial. 
nor, sin embargo, habría sido mejor solución la creación de una norma capaz de abarcar los distintos supuestos que pueden acontecer en la práctica para que no ocurriera lo que ha ido ocurriendo durante años: la consideración de atipicidad de cientos de casos que representaban auténticas sustracciones.

Pues bien, la realidad es que antes de la reforma de 2021 no se permitía la aplicación del delito de sustracción de menores (al menos en la modalidad de traslado) al progenitor que tuviera atribuida la guarda y custodia de los hijos. De esta manera, se sancionaba la conducta del progenitor que, aprovechando el régimen de visitas, sustraía al menor y no lo devolvía cuando correspondía. Por el contrario, quedaban fuera del tipo aquellos supuestos en los que era el custodio el que trasladaba al menor de manera unilateral al lugar donde quisiera, sin contar con el consentimiento del otro progenitor no custodio pero ejerciente de la patria potestad y aquellos otros casos en los que uno de los dos progenitores, antes de iniciar el proceso judicial oportuno, se trasladaba con el menor sin previo aviso. Tampoco parecían tener cabida a nivel jurisprudencial los supuestos en que era el custodio el que retenía al menor impidiendo el correcto desarrollo del régimen de visitas. Estos dos últimos grupos de casos, aun cuando podían encajar perfectamente en la redacción típica, solían ser considerados atípicos por la Jurisprudencia. Esta situación se debía a la interpretación jurisprudencial de que el delito requería siempre la existencia de una resolución judicial con atribución de la guarda y custodia a alguno de los dos progenitores (o a un tercero), por lo que el criterio resolutorio en el más que frecuente caso del progenitor cuidador habitual que se traslada antes incluso del inicio del proceso de separación pasaba por la atipicidad de la conducta. Si bien es cierto que existe una minoría de casos enjuiciados que han condenado por sustracción de menores este tipo de supuestos y de la importancia de una Sentencia de la Audiencia Nacional ${ }^{62}$, que llamaba la atención acerca de lo erróneo de dicho criterio, siendo que dicho comportamiento debería integrar el delito de sustracción de menores, la realidad es que la gran mayoría de sentencias jurisprudenciales dictaminan (o lo hacían antes de la reforma de 2021) la impunidad de esta clase de conductas.

Esa creencia de que solo el progenitor custodio podía cometer el delito fue lo que motivó la falta de aplicación a aquel también en los casos de retención, de forma que era posible aplicarlo en aquellos casos en los que el padre no devolvía al menor tras el cumplimiento del régimen de visitas pero no en los supuestos en que el padre custodio impedía el desarrollo de dichas visitas mediante la retención del menor, algo que ya resultaba criticable antes de la reforma. En vista de que la Exposición de Motivos de la LO 8/2021, de 4 de junio, expresa que el motivo por el que se modifica el precepto objeto de estudio no es otro que permitir que el tipo sea aplicable a ambos progenitores, con independencia de si disponen o no de la guarda y custodia y teniendo en cuenta que la modificación solo ha operado sobre la modalidad de traslado (que era la que inicialmente recogía de manera expresa que solo el custodio podía consentir en el traslado, lo que implicaba que dicha persona podía trasladar al menor de forma impune) y no se ha modificado la modalidad de retención ${ }^{63}$, puede extraerse que ya antes de la mencionada reforma era posible aplicar el tipo a los padres custodios. Esto es así porque si solo ha sido necesaria la modificación

62 SAN 10/2016, de 15 de marzo.

63 El tipo solo ha cambiado su redacción utilizando un lenguaje más inclusivo, sustituyendo la expresión "menor de edad" por "persona menor de edad". 
del traslado y el sentir de la reforma es otorgar a ambos progenitores los mismos derechos, ello quiere decir que en la modalidad de retención ya existía una equiparación. Sin embargo, la Jurisprudencia y la doctrina mayoritarias no admitía la aplicación del tipo al custodio que impedía el régimen de visitas ${ }^{64}$, existiendo pocas opiniones discrepantes de esta idea, esto es, consonantes con lo defendido en este artículo ${ }^{65}$.

Como se mencionaba anteriormente, la sustracción podía producirse a través de un traslado sin el consentimiento del progenitor o el custodio (en el caso de que sea una tercera persona o el menor esté bajo el cuidado de alguna institución) o mediante la retención del menor de forma que se incumpliera gravemente una resolución judicial o administrativa.

Por cuanto atañe al traslado, trasladar implica desplazar a una persona o a una cosa de un lugar a otro. En este caso, el traslado supone que el progenitor, ascendiente del menor o pariente del primero hasta segundo grado va a trasladarlo desde el lugar de residencia hasta otro sitio. Un traslado, como su propio nombre indica, expresa una realidad en la que existe un desplazamiento, debiendo producirse una modificación del lugar de residencia ${ }^{66}$. Esta expresión de "lugar de residencia" puede dar lugar a distintas interpretaciones, siendo que lo correcto es entender que se refiere al domicilio familiar u otro en el que el menor se encuentre con anuencia de sus padres o guardadores ${ }^{67}$. En cualquier caso, se trata siempre de una conducta activa, no cabe realizar un traslado por omisión.

Por cuanto respecta a la naturaleza, la modalidad de traslado constituye un delito de resultado ${ }^{68}$, mientras que la de retención se configura como un delito de mera actividad. Por ende, será necesario encontrar esa conexión causal entre la conducta del sustractor y el resultado típico, concretado este en la modificación del lugar de residencia del menor sin el consentimiento apropiado ${ }^{69}$.

El consentimiento del otro progenitor, expresado de forma libre, sin vicios y siendo consciente de lo que se está consintiendo constituye una causa de atipicidad, quedando el bien jurídico protegido inerte. Efectivamente, el consentimiento a la lesión del bien jurídico entraña un supuesto de atipicidad porque, si el titular goza de la libre disposición sobre ciertos bienes jurídicos (no todos son disponibles), no es que ese consentimiento justifique la conducta. Si se considera que el consentimiento es una causa de justificación se estaría afirmando la existencia de una conducta típica, y en principio antijurídica, que al final acaba convertida en una situación lícita precisamente al encontrarnos en una situación permitida por el Ordenamiento jurídico. Con todo, cuando el sujeto consiente, esa agresión no llega a nacer. Esto se desprende también de la propia esencia del Derecho penal, si la función principal del Derecho penal no es otra que la protección de los bienes jurídicos, si el titular del mismo consiente en esa lesión, esa protección deviene innecesaria, por lo que será penalmente irrelevante. Esto será así siempre y cuando el bien jurídico sea

64 Vid. por todos, ESPINOSA CEBALLOS, E. El delito de sustracción de un menor por su progenitor, Tirant lo Blanch, Valencia, 2014, p. 58.

65 Así, LLORIA GARCÍA, P. “La regulación penal...”, Ob. cit., p. 55.

66 En línea similar, STERN BRIONES, E. "La sustracción parental de menores”, Estudios jurídicos, nº 2007, 2007, pp. 9-10 y DÍEZ RIPOLLÉS, J.L. "El nuevo delito de...", Ob. cit., p. 299.

67 STERN BRIONES, E. "La sustracción parental...", Ob. cit., p. 9.

68 De la misma opinión, QUERALT JIMÉNEZ, J. Derecho Penal Español. Parte Especial, 7 a ed., Tirant Lo Blanch, Valencia, 2015, p. 423.

69 ESPINOSA CEBALLOS, E. El delito de sustracción..., Ob. cit., p. 51. 
plenamente disponible por el titular. Por ende, si el sujeto goza del consentimiento de la persona a la que corresponde decidir sobre el menor, no es que la conducta esté justificada, sino que desde el principio no hay lesión del bien jurídico, la conducta deviene atípica.

Resulta ampliamente criticable que no se haya incluido como causa de atipicidad el consentimiento libremente otorgado por el propio menor de edad con una capacidad suficiente para decidir, algo que demuestra que los menores han sido completamente olvidados por el legislador, que se ha limitado a proteger los derechos de los padres. No obstante, comoquiera que el precepto alude a que la sustracción debe realizarse sin causa justificada, debería apreciarse que un consentimiento de estas características justificaría la conducta, quedando esta atípica, dado que la ausencia de causa justificada constituye un elemento del tipo, luego no cabría afirmar que el consentimiento del menor constituye una causa de justificación, antes al contrario, sería una causa de atipicidad.

En lo tocante a la retención, se trata de un delito de omisión propia. Como elementos típicos de los delitos omisivos se han mencionado la situación típica (el presupuesto de hecho que da origen al deber de actuar y que varía según el tipo específico), la ausencia de realizar la acción mandada y la capacidad personal de realizar la acción ${ }^{70}$, incluyendo el dolo el conocimiento de esa situación que genera el deber de actuar ${ }^{71}$. Efectivamente, la retención implica un deber de entrega del menor a la persona que corresponda, el sujeto no procede a esa entrega aun pudiendo hacerlo y ello da como resultado la aparición del tipo de sustracción de menores.

En principio, la retención es un delito de mera actividad porque solo con retener al menor, el tipo se cumpliría. Sin embargo, debe tenerse en cuenta que el legislador incluye un elemento adicional, el incumplimiento grave de una resolución judicial o administrativa, es necesario que ese resultado se produzca. Por consiguiente, una retención que no se manifieste en ese incumplimiento grave no dará lugar a la aplicación del tipo. Ello expresa que, si, por ejemplo, se retiene el menor durante un periodo de tiempo insignificante, un mero retraso en la entrega, no existe ese resultado y, por ende, tampoco el delito.

Por supuesto, la modalidad de retención es aplicable a casos de custodia compartida, pues, como apunta la doctrina, se altera la estabilidad del menor, se priva al progenitor custodio de su derecho a relacionarse con el hijo y se quebranta una resolución judicial ${ }^{72}$. En la custodia compartida, el tipo es perfectamente aplicable porque siempre existe una resolución que la ha acordado. Desde el momento en que uno de los padres no devuelve al menor cuando comienza el tiempo del otro, la conducta integra el tipo de retención, sin perjuicio de que los hechos puedan englobar, asimismo, una conducta de traslado.

El tipo penal de sustracción de menores indica, ab initio, que el comportamiento requiere la ausencia de una causa justificada ${ }^{73}$. Este inciso no debe interpretarse coinci-

70 DEMETRIO CRESPO, E. Curso de Derecho Penal. Parte General (coord. DEMETRIO CRESPO, E. y RODRÍGUEZ YAGÜE, C.), 3ª ed., Ediciones Experiencia, Barcelona, 2016, p. 232.

71 MORENO-TORRES HERRERA, $\mathrm{M}^{\mathrm{a}}$ R. Lecciones de Derecho Penal. Parte General, 2a ed., (dir. ZUGALDÍA ESPINAR, J. M.), Tirant lo Blanch, Valencia, 2015, p. 236.

72 DE LA ROSA CORTINA, J. M. "El delito de sustracción de menores: última jurisprudencia", Repertorio JurídicoCientífico del Centro de Estudios Jurídicos, 2017, p. 24.

73 Por consiguiente, la esencia diferenciadora del delito de sustracción de menores es que la ausencia de una causa que justifique la conducta aparece expresamente descrita en la conducta, luego si aparece una causa de justificación, la misma no participará de la naturaleza del resto de causas de justificación que sirven para negar a posteriori 
dente con las causas de justificación ${ }^{74}$, sino que ha de ser dotado de un contenido más amplio $^{75}$. Así, se ha indicado la posibilidad de incluir "aquellos sucesos que, de una manera razonable y solemne, acorde a los hechos y circunstancias de cada caso, permitan explicar el traslado del menor del progenitor o institución que tengan en ese momento su guarda y custodia"76; o "cualquier circunstancia que, sin poner en peligro la seguridad del menor, permitan fundar la no restitución" "77. Esto es, cualquier circunstancia que permita fundar ese no reintegro ponderando todos los elementos que concurran en el momento de invocar la justificación ${ }^{78}$.

En conclusión, debe suponerse que, cuando el legislador utiliza la expresión "causa justificada", se está refiriendo a un motivo razonable por el cual el progenitor o el sujeto activo en cuestión haya actuado de tal manera, ejecutando lo que en un principio podría considerarse una sustracción de menores aunque finalmente no sea así, toda vez que la conducta sería desde un primer momento atípica y, por tanto, carente de cualquier tipo de relevancia penal. El criterio jurisprudencial también parece coincidir en esta interpretación. La realidad demuestra que los tribunales han ido acogiendo como causas justificadas supuestos que nada tienen que ver con incumplimientos de Derechos humanos o situaciones de peligro para la salud o la vida del menor, sino más bien con la alegación de motivos más o menos razonables ${ }^{79}$. Así, por ejemplo, se ha apreciado en supuestos de malos tratos ${ }^{80}$, circunstancias personales ${ }^{81}$, o, incluso cuando la sustracción obedece al deseo de evitar otra sustracción ${ }^{82}$.

la ilicitud de un comportamiento que a priori parece ilícito, sino que actuaría como causa de atipicidad, porque faltaría un elemento del tipo.

74 En contra, ARROYO ALFONSO, S. "Tendencias del Derecho Penal”, Derecho y conocimiento, vol. 2, 2002, p. 443 y DÍEZ RIPOLLÉS, J.L. "El nuevo delito de...", Ob. cit., p. 301.

75 En la misma línea, STERN BRIONES, E. “La sustracción parental...”, Ob. cit., p. 12.

76 SÁNCHEZ LINDE, M. "La sustracción de menores en el Código Penal”, La Ley Penal, núm. 101, marzo-abril 2013, p. 102. En la misma línea, GONZÁLEZ RUS, J. J. Derecho Penal Español. Parte Especial, (coord. COBO DEL ROSAL), Dykinson, $2^{\mathrm{a}}$ ed., Madrid, 2005, p. 433.

77 FERNÁNDEZ BAUTISTA, S. Manual de..., Ob. cit., p. 399.

78 TORRES ROSELL, N. Comentarios a la parte especial del Derecho Penal (dir. QUINTERO OLIVARES, G.), 10 ${ }^{\mathrm{a}}$ ed., Aranzadi, Navarra, 2016, p. 582.

79 LLORIA GARCÍA, P. "La regulación penal...", Ob. cit., p. 63.

80 La Audiencia Provincial de Madrid (Auto núm. 302/2004, de 17 de junio) consideró que el hecho de que una madre se trasladara con los hijos del domicilio familiar no constituía delito porque la conducta fue realizada por miedo a que el marido (ya condenado por maltrato verbal) pudiera cometer cualquier acto violento también contra ellos. Al estimarse que la conducta estaba justificada, se señala directamente la atipicidad de la misma.

81 Así, el Juzgado de Instrucción número 12 de Barcelona decretaba, por medio de Auto con fecha de 26 de mayo de 2006, el sobreseimiento provisional de las actuaciones abiertas por un delito de sustracción de menores al entender que concurría una causa justificada para la conducta de una madre que había abandonado el domicilio familiar con los hijos, afirmando la atipicidad de la misma por los siguientes extremos: la madre había puesto previo aviso al padre del traslado y había iniciado el proceso de separación legal; la conducta estaba en sí misma justificada por cuanto la mujer había solicitado una orden de protección frente al marido por malos tratos; el traslado se había producido debido a que los padres de la denunciada se encontraban enfermos y esta debía ocuparse de los cuidados necesarios; y el menor no se encontraba en situación de desamparo porque estaba conviviendo tanto con la madre como con los abuelos maternos.

82 Así lo afirma la Audiencia Provincial de Madrid en su Auto núm. 622/2006, de 11 de diciembre. En este enrevesado caso, la Jurisprudencia se muestra partidaria de considerar causa justificada el riesgo de que el menor sea efectivamente sustraído por el progenitor que está denunciando al otro justamente por el mismo delito. El padre (progenitor denunciado) retuvo al menor porque existían indicios de que la madre pretendía trasladar al hijo a Bolivia y había sido informado de ello, insólitamente, por la hermana de la denunciante (lo que aumenta la credibilidad de la noticia). Es más, el denunciado actuó con la máxima diligencia poniendo en conocimiento en todo momento a las autoridades de lo que estaba sucediendo e iniciando al mismo tiempo un proceso civil para 
Debe destacarse, asimismo, que se ha considerado como causa justificada el consentimiento del propio menor de edad, con madurez suficiente para decidir, decantándose los tribunales por la atipicidad en este supuesto, al igual que se veía con ocasión del estudio del art. $224 \mathrm{CP}$, donde la Jurisprudencia rechaza la tipicidad en aquellos casos en que no existe inducción, sino una decisión tomada voluntariamente por quien no es aún mayor de edad pero sí muestra capacidad suficiente para decidir sobre algunas cuestiones.

Así, se confirmó el sobreseimiento provisional dictado por un Juzgado de Instrucción en un caso en que, ostentando el padre la guarda y custodia de los dos hijos menores, se denunció a la madre por un delito de sustracción de menores al mantener a los dos niños viviendo con ella. Estos contaban con 16 años cuando se les realizó una exploración psicológica y declararon que se habían ido de casa de su padre porque se encontraban mal allí y que estaban viviendo con su madre porque así lo deseaban ${ }^{83}$; o con ocasión de un recurso de apelación ${ }^{84}$, donde la Audiencia Provincial de Vigo hace especial hincapié en la presencia o ausencia del dolo característico del delito del que se viene hablando, consistente en la intención de privar al otro progenitor de relacionarse con el menor. Sin embargo, en este caso era el propio menor de 12 años el que se fue voluntariamente con su padre, sin romper en ningún momento las relaciones con la madre, a la que veía regularmente y con la que pasaba periodos vacacionales. Así las cosas, no considera que el bien jurídico protegido se haya visto lesionado. También se ha adoptado este criterio dentro de la esfera de casos en que ambos progenitores conjuntamente llevan a cabo la conducta ${ }^{85}$.

Por cuanto concierne a la culpabilidad, el delito ha de cometerse con dolo, sin que se exija ningún otro elemento subjetivo del tipo ${ }^{86}$, si bien es necesario que la conducta presente cierta entidad para no quebrantar el principio de intervención mínima ${ }^{87}$.

En el caso del traslado, el dolo ha de recaer sobre el propio traslado, debe conocerse la ausencia del consentimiento por parte de quien deba otorgarlo y, en su caso, la salida del territorio nacional o la exigencia de la condición para reintegrarlo. El sujeto conoce estos ele-

solicitar la atribución de la guarda y custodia, tanto es así, que es el propio Ministerio Fiscal el que ampara la situación, otorgando temporalmente la custodia del menor al padre en tanto se resolvía el asunto.

84 SAP Vigo núm. 293/2016, de 16 de junio.

85 Esto aconteció, por ejemplo, en la SAP Tarragona núm. 488/2018, de 9 de noviembre. Así, el 20 de enero de 2016 se dictó una resolución por parte de la Dirección General de Atención a la Infancia y a la Adolescencia de la Generalitat de Cataluña declarando el desamparo de una menor, Gloria. Esta fue trasladada a un centro de acogida. En febrero del mismo año, se habilitó un régimen de comunicación con la familia, de manera que Gloria podía pasar un día a la semana con sus padres, incluyendo pernocta, desde el sábado por la mañana, hasta el domingo por la noche. Durante la Semana Santa, los padres podían permanecer en compañía de Gloria durante 4 días. Pero, en lugar de cumplir el régimen, aprovecharon para trasladarla a Marruecos sin consentimiento del centro y ya no regresaron a España hasta diciembre de ese año, momento en el que Gloria ya había alcanzado la mayoría de edad. El Juzgado de lo Penal número 3 de Tarragona condenó a ambos por un delito de sustracción de menores a la pena de tres años, seis meses y un día de prisión y ocho años de inhabilitación especial para el ejercicio de la patria potestad (debido al componente internacional, que agrava la pena). En apelación, la Audiencia Provincial de Tarragona cambia el criterio del Juzgado y se centra en determinados elementos: en primer lugar, no se puede acreditar que los padres pudieran conocer el alcance de la resolución ni las consecuencias del incumplimiento debido a las grandes dificultades idiomáticas y culturales que aquellos presentaban; en segundo lugar, recuerda que Gloria contrajo matrimonio durante su estancia en Marruecos y que esta contaba con 17 años y medio, siendo que la menor había declarado haberse marchado voluntariamente del país y haber contraído matrimonio también de manera voluntaria, volviendo luego con su marido a territorio español. Todos estos datos le llevan a concluir que los padres no deben quedar sujetos a responsabilidad penal. Estima el recurso de apelación y absuelve del delito de sustracción de menores.

86 Idea compartida por el propio Tribunal Supremo en la STS 339/2021, de 23 de abril.

87 Así, también, la SAP Madrid núm. 203/2007, de 8 de junio. 
mentos y toma una decisión contraria al bien jurídico, se posiciona en contra de los derechos de responsabilidad parental o de custodia y los lesiona. La modalidad de retención constituye un delito omisivo. Para que la culpabilidad pueda afirmarse, es necesario que el sujeto sea consciente de que tiene ese deber de entrega y adopte la decisión de no proceder al mandato.

El delito de sustracción de menores queda consumado en el momento en que se verifica el traslado o en el momento en que se produce la retención que integra ese grave incumplimiento de una resolución judicial o administrativa. Además, al ser un delito permanente, permanece en estado consumativo hasta que se pone fin a la lesión al bien jurídico, motivo por el que se permite cualquier tipo de participación incluso en esta fase ${ }^{88}$. Por supuesto, son posibles los casos de tentativa. Es crucial reseñar que, en este delito, todos los supuestos de tentativa, en tanto no sobrepasen las veinticuatro horas de duración, deberían reconducirse a la excusa absolutoria prevista en el cuarto apartado del art. 225 bis. Lo contrario no tendría sentido, pues implicaría castigar menos duramente un delito consumado que no excede de veinticuatro horas que un supuesto de delito intentado. De esta forma, si el delito consumado puede beneficiarse de la aplicación de la excusa absolutoria, quedando el sujeto exento de pena, sería descabellado condenar al sujeto que no llega a consumar la sustracción, con la pena del tipo básico rebajada en uno o dos grados.

Este delito se encuentra castigado con una pena de prisión de entre dos y cuatro años y una inhabilitación especial para el ejercicio de la patria potestad de entre cuatro y diez años. Sin embargo, la pena se impondrá en su mitad superior si se cumple alguna de las dos circunstancias que plantea el tipo agravado del tercer apartado del art. 225 bis: el traslado del menor fuera del territorio nacional, en vista de la mayor dificultad de localización y retorno del menor en tal supuesto; o la exigencia de una condición para la restitución del menor, toda vez que se afecta la voluntad de decisión del padre no sustractor o de la persona a quien corresponda su cuidado o custodia en términos similares a lo que ocurre con los delitos de amenazas ${ }^{89}$.

Por el contrario, la pena será privativa de libertad de entre seis meses y dos años en el caso de que la sustracción sea de una duración inferior a quince días, tal y como marca el tipo atenuado del apartado cuarto del art. 225 bis, algo que encuentra sentido en la menor afección que sufre el bien jurídico protegido al poseer la sustracción escasa duración.

Finalmente, ha de destacarse que el primer inciso del apartado cuarto del art. 225 bis establece una excusa absolutoria para el caso de que la sustracción no haya superado las 24 horas de duración, resultando criticable que la exención obedezca a un criterio distinto al hecho de que el sujeto activo realice un comportamiento postdelictivo de signo positivo $^{90}$, o cuando es este quien comunica a quien corresponda el lugar en el que se encuentra el menor dentro de las 24 horas siguientes a la sustracción, comprometiéndose a devolverlo y cumpliendo dicha promesa. Todos los plazos comienzan a computarse en el momento de la interposición de la denuncia, tal y como marca el precepto.

88 También DEL ROSAL BLANCO, B. se muestra a favor de la participación en los delitos permanentes, siempre y cuando se vayan incorporando distintos sujetos a la ejecución (permanente), mientras se mantenga la situación de privación de libertad (en relación con los tipos de detención ilegal). En Sistema de Derecho penal. Parte especial (dir. MORILlAS CUEVA, L.), Dykinson, $3^{\text {a }}$ ed., Madrid 2020, p. 140.

89 En términos similares, MARTÍNEZ GARCÍA, A. S. Comentarios prácticos al Código penal, vol. II (dir. GÓMEZ TOMILLO, M.), $1^{\text {a }}$ ed., Thomson Reuters Aranzadi, Pamplona, 2015, p. 866.

90 Así lo entiende también STERN BRIONES, E. "La sustracción parental...”, Ob. cit., p. 17. 


\section{RELACIÓN ENTRE AMBOS PRECEPTOS}

La relación que une al art. 224 y 225 bis CP no solo es penológica, en el sentido de que el tipo atenuado de sustracción de menores castiga con la misma pena que el tipo básico del delito de inducción al hijo a la infracción del régimen de custodia. Tampoco aparecen conectados simplemente por ser hijos de la misma Ley Orgánica, sino que es algo que va más allá.

En este sentido, se ha interpretado esa conexión entre ambos artículos aludiendo al hecho de que en el art. 224. 2 CP existe un consentimiento, si bien inválido, mientras que en el art. 225 bis dicho consentimiento no existe, bien porque el menor no lo presta o bien porque es tan pequeño que carece incluso de una mínima capacidad de decisión ${ }^{91}$.

Igualmente, se ha mencionado que la relación entre ambos artículos pasaría por ser un concurso de normas, toda vez que el art. $224 \mathrm{CP}$ es una forma de participación en un hecho ajeno, que queda consumida por la conducta de autoría que lleve a cabo el propio inductor $^{92}$. Esto es, si el progenitor induce al menor a que abandone su lugar de residencia, el delito aplicable sería el del art. 224.2 CP, siendo que la sustracción quedaría absorbida por aquel ${ }^{93}$.

Asimismo, se ha indicado que cuando el menor de edad presenta un grado de inimputabilidad muy elevado, existirá un pleno control del hombre de atrás, quiere decirse, existirá autoría mediata, por lo que, en lugar de aplicar el art. 224.2 CP, debería aplicarse el art. 225 bis; sin embargo, si lo que existe es inducción, sin posterior control, la conducta se encuadra en el primero de los artículos mencionados, igual que cuando se trata de menores próximos a la mayoría de edad ${ }^{94}$. Precisamente, la primera de las figuras mencionadas presupone en el hijo menor de edad una cierta autonomía personal para llevar a cabo su propia sustracción al contenido obligacional fijado por el régimen de custodia ${ }^{95}$. Por ende, es de vital importancia que el menor disponga de una mínima capacidad para poder ser inducido, debiendo negarse la aplicación del art. 224.2 CP en aquellos casos en los que el menor es tan pequeño que no puede ser manipulado en el sentido de la inducción que arbitra el precepto porque no es capaz de tomar ninguna decisión, ya sea influida por otra persona o no. Si el menor se encuentra en esa situación, el tipo aplicable será más bien el de sustracción de menores, en caso contrario, si ya puede tomar algunas decisiones, la sustracción será más difícil, optando el sujeto activo por la persuasión para la infracción al régimen de custodia.

Esta conexión también ha sido apreciada por la Jurisprudencia, como muestra la Audiencia Provincial de Granada al confirmar la imposibilidad de subsumir los hechos en el art. 224.2 CP al recaer la conducta sobre un bebé de escasos meses de edad, por cuanto la razón más evidente es la imposibilidad material para cualquier adulto de determinar mediante inducción eficaz la voluntad de una niña de meses de edad para que

91 FERNÁNDEZ BAUTISTA, S. Manual de..., Ob. cit., p. 401.

92 ROCA AGAPITO, L. Tratado de Derecho Penal..., Ob. cit., p. 1699.

93 DÍEZ RIPOLLÉS, J.L. "El nuevo delito de...", Ob. cit., p. 314.

94 MOLINA FERNÁNDEZ, F. Memento Práctico..., Ob. cit., p. 1251.

95 TORRES FERNÁNDEZ, Ma E. "Los nuevos delitos de...”, Ob. cit., p. 1815. 
esta observe un determinado comportamiento que infrinja un régimen jurídico personal determinado por el Juez o la autoridad administrativa ${ }^{96}$.

Efectivamente, la inducción a un bebé es imposible porque su capacidad de decisión es nula, por lo que la conducta se concretará en una sustracción, pues a un bebé no se le ha de convencer de dónde residir, sino que lo fácil será sustraerlo y trasladarlo al sitio querido por el progenitor sustractor.

En términos similares, se pronuncia la Audiencia Provincial de Girona, indicando que la conducta de la madre que se lleva a su hija del domicilio familiar no podía encajar en el tipo del art. 224.2 CP, dado que el abandono del domicilio familiar debe verificarse voluntariamente por él mismo y que a la formación de dicha voluntad haya contribuido de manera eficaz la conducta del sujeto activo, lo que requiere que el menor o discapacitado posea una mínima capacidad de decisión, algo que se encuentra ausente en un niño de dos años, que por sí mismo no puede adoptar ninguna decisión, ni siquiera siendo esta viciada por la influencia de una tercera persona ${ }^{97}$.

Como ya se ha mencionado, la conducta del menor que por propia iniciativa abandona su lugar de residencia quedaría fuera del tipo, pudiendo aplicarse el artículo 224 $\mathrm{CP}$ si consta la existencia de una inducción ${ }^{98}$. Esta idea es completamente lógica, quiere decirse, si el menor de edad ya ha alcanzado una edad suficiente como para poder tener cierta libertad de movilidad, algo que es posible en la adolescencia, y es quien, por propia iniciativa, decide cambiar su lugar de residencia para pasar a vivir con el otro progenitor, la responsabilidad de dicho progenitor a tenor del delito de sustracción de menores resulta forzada, toda vez que este no ha cometido conducta delictiva alguna, su actuación se limitaría a dar cobijo al menor. Ahora bien, si el sustrato de esa decisión bebe de la inducción por parte de aquel, entonces existirá responsabilidad penal, pero no por un delito de sustracción de menores, sino por un delito de inducción a la infracción del régimen de custodia.

Cuando se hace referencia a menores de corta edad, es obvio que su consentimiento no es apto para descartar el tipo de sustracción de menores. Aún son demasiado pequeños para poder tomar una decisión, les falta madurez y sus decisiones se basan en lo que ellos consideran beneficioso a pesar de que, objetivamente hablando, sea justo lo contrario a lo que marca su interés superior. No puede ser de otra manera, los padres deben velar por sus hijos porque ellos no pueden valerse por sí mismos hasta alcanzar determinada edad, lo cual redunda también en una incapacidad para tomar decisiones factibles. No obstante, cuando son adolescentes la conclusión habría de ser diferente parcialmente: un adolescente de esa edad no dispone aún de plena capacidad de obrar para decidir acerca de algunos aspectos de su vida porque la ley no se lo permite, lo cual no quiere decir que deba negarse toda eficacia o validez a sus decisiones ${ }^{99}$. En otras palabras, la conducta del art. 224.2 CP se producirá en aquellos casos en los que el niño no es tan pequeño como para

96 AAP Granada núm. 865/2017, de 20 de noviembre.

97 AAP núm. 18/2000, de 20 de enero.

98 DÍEZ RIPOLLÉS, J.L. "El nuevo delito de...”, Ob. cit., p. 295.

99 En esto difiere el Código Penal español de la normativa italiana, en tanto esta última recoge tres tipos diferentes de sustracción de menores, el primero de los cuales, tipificado en el artículo 573 del Código Penal, se refiere a la sustracción de un menor mayor de catorce años que haya prestado su consentimiento, con lo cual, se tiene en cuenta el consentimiento del menor para integrar un tipo delictivo castigado con una pena más leve que cuando la sustracción se produce sobre una persona menor de catorce años o discapacitada. 
no poder tomar sus propias decisiones ${ }^{100}$. Por ello, se ha apuntado que, a diferencia de lo que ocurre en el art. 225 bis CP, donde uno de los titulares de la patria potestad procede a la separación física del menor con respecto del otro, en el art. $224 \mathrm{CP}$ esto se produce por medio de una inducción, donde el adulto limita la libertad o autonomía del menor ${ }^{101}$. Si el progenitor sustrae, el comportamiento se incardina en el delito de sustracción de menores y si hace al hijo sustraerse por medio de una inducción, el tipo aplicable es el de inducción a la infracción del régimen de custodia. Por otro lado, se comparte la idea acerca de que, si el consentimiento es libremente adoptado, la conducta no se podrá perseguir ni por el artículo 224 ni por el artículo 225 bis $^{102}$.

Sintetizando lo anterior, cabe arrojar las tres principales conclusiones que se devengan del presente estudio: si el titular de la patria potestad lleva a cabo la sustracción por sí mismo, aprovechando la corta edad del menor, la conducta integrará un delito de sustracción de menores del art. 225 bis CP; si el titular de la patria potestad induce a que sea el propio menor el que se sustraiga al régimen de custodia establecido (entendiendo el término en sentido amplio y pudiendo producirse dicha inducción tanto para sustraerse a la guarda y custodia como al régimen de visitas), la conducta integrará un delito de inducción al hijo menor a infringir el régimen de custodia del art. $224 \mathrm{CP}$, resultando crucial que el menor presente edad suficiente como para poder tomar una decisión, aun influida por el progenitor, esto es, debe poder ser influido, debe poder prestar un consentimiento (aunque viciado, de ahí que la conducta sea delictiva); si el menor ha tomado esa decisión libremente, sin influencia alguna, y presenta una edad suficiente como para poder tomar decidir por sí mismo, la conducta quedará atípica, siendo lo más adecuado de lege ferenda introducir una edad que actúe como criterio objetivo para saber cuándo el consentimiento del menor determina la atipicidad de la conducta. Y es que carece de sentido que toda la legislación actual se oriente en la dirección de reconocer al menor cada vez mayor autonomía y capacidad de decisión conforme va creciendo hasta alcanzar la plena capacidad de obrar al cumplir la mayoría de edad y, sin embargo, su consentimiento a la hora de decidir algo tan importante como la persona o el lugar en el que desea vivir (siempre que ello no le ocasione un perjuicio) no presente valor alguno.

100 LLORIA GARCÍA, P. “La regulación penal...”, Ob. cit., p. 71.

101 TORRES FERNÁNDEZ, Ma E. "Los nuevos delitos de...,", Ob. cit., p. 1815.

102 LLORIA GARCÍA, P. “La regulación penal...”, Ob. cit., p. 72. 